\title{
A rapid live-cell ELISA for characterizing antibodies against cell surface antigens of Chlamydomonas reinhardtii and its use in isolating algae from natural environments with related cell wall components
}

Wenzhi Jiang ${ }^{1}$, Sarah Cossey², Julian N Rosenberg ${ }^{3,4}$, George A Oyler ${ }^{3,4}$, Bradley JSC Olson² and Donald P Weeks ${ }^{1 *}$

\begin{abstract}
Background: Cell walls are essential for most bacteria, archaea, fungi, algae and land plants to provide shape, structural integrity and protection from numerous biotic and abiotic environmental factors. In the case of eukaryotic algae, relatively little is known of the composition, structure or mechanisms of assembly of cell walls in individual species or between species and how these differences enable algae to inhabit a great diversity of environments. In this paper we describe the use of camelid antibody fragments (VHHs) and a streamlined ELISA assay as powerful new tools for obtaining mono-specific reagents for detecting individual algal cell wall components and for isolating algae that share a particular cell surface component.
\end{abstract}

Results: To develop new microalgal bioprospecting tools to aid in the search of environmental samples for algae that share similar cell wall and cell surface components, we have produced single-chain camelid antibodies raised against cell surface components of the single-cell alga, Chlamydomonas reinhardtii. We have cloned the variable-region domains $\left(V_{H} H s\right)$ from the camelid heavy-chain-only antibodies and overproduced tagged versions of these monoclonal-like antibodies in E. coli. Using these $\mathrm{V}_{H} \mathrm{Hs}$, we have developed an accurate, facile, low cost ELISA that uses live cells as a source of antigens in their native conformation and that requires less than 90 minutes to perform. This ELISA technique was demonstrated to be as accurate as standard ELISAs that employ proteins from cell lysates and that generally require $>24$ hours to complete. Among the cloned $\mathrm{V}_{\mathrm{H}} \mathrm{Hs}, \mathrm{V}_{\mathrm{H}} \mathrm{H} \mathrm{B} 11$, exhibited the highest affinity $\left(\mathrm{EC}_{50}<1 \mathrm{nM}\right)$ for the C. reinhardtii cell surface. The live-cell ELISA procedure was employed to detect algae sharing cell surface components with $C$. reinhardtii in water samples from natural environments. In addition, mCherry-tagged $V_{H} H$ B11 was used along with fluorescence activated cell sorting (FACS) to select individual axenic isolates of presumed wild relatives of $C$. reinhardtii and other Chlorphyceae from the same environmental samples.

Conclusions: Camelid antibody $\mathrm{V}_{\mathrm{H}} \mathrm{H}$ domains provide a highly specific tool for detection of individual cell wall components of algae and for allowing the selection of algae that share a particular cell surface molecule from diverse ecosystems.

Keywords: Live-cell ELISA, Camelid antibodies, Algae, Cell walls, $V_{H} H$, Chlamydomonas, Chlorophyceae, Cell wall conservation, Nanobodies

\footnotetext{
*Correspondence: dweeks1@unl.edu

'Department of Biochemistry, University of Nebraska-Lincoln, 1901 Vine

Street, Lincoln, NE 68588, USA

Full list of author information is available at the end of the article
} 


\section{Background}

The cell walls of land plants and algae provide physical support and protection against various environmental factors and stresses. While much is known about plant cell walls [1], our knowledge of algal cell walls is more rudimentary [2,3]. Although it is known, for example, that cell walls of algae and land plants can contain abundant hydroxyproline-rich glycoproteins e.g., [4,5], studies of the composition and structure of algal cells walls and the diversity of cell wall components within and between algal species lag far behind that of land plants. Thus, detailed comparisons of cell wall compositions, synthesis and deposition between land plants and algae (and between different species of algae) are not presently possible. To help address this deficiency, we sought to develop techniques that would allow identification of cell surface-specific molecules not only in one particular alga, but also in closely related algal species in a variety of environmental locations. Monoclonal antibodies raised against such cell wall proteins, glycoproteins and other components have been used in the recent past as a powerful tool for allowing detection and characterization of plant and algal cell wall components [6,7] and have potential as a highly valuable tool for isolation of algae with shared cell surface constituents. An alternative approach that provides the same single-molecule specificity as conventional monoclonal antibodies involves use of camelid antibodies [8] that are composed of a single heavy chain molecule and used widely as highly specific, high affinity antibodies for numerous applications [9-12]. Genes encoding the singledomain antigen-binding fragment $\left(\mathrm{V}_{\mathrm{H}} \mathrm{H}\right)$ of camelid heavychain-only antibodies [that we will refer to generically as $\mathrm{V}_{\mathrm{H}} \mathrm{Hs}$ or, alternatively, single-domain antibodies (sdAbs) or nanobodies] can be cloned into bacteriophage-based expression vectors that allow a phage-display library of clones to be "panned" for $\mathrm{V}_{\mathrm{H}} \mathrm{Hs}$ against a particular target antigen $[13,14]$. (Multiple targets can screened simultaneously in the initial panning). Individual cloned genes are modified to produce tagged $\mathrm{V}_{\mathrm{H}} \mathrm{H}$ that can be readily detected during ELISA assays to measure their affinity for the target antigen or, for example, in the selection of algal species expressing the target antigen on their cell surface. As an initial proof-of-concept for this approach we chose to utilize Chlamydomonas reinhardtii (hereafter referred to as Chlamydomonas) as the alga whose cell wall is the most studied to date [3,5].

To generate camelid antibodies against Chlamydomonas antigens, we immunized alpacas with whole cell extracts of Chlamydomonas and prepared phage-display libraries of genes encoding variable-domain $\left(\mathrm{V}_{\mathrm{H}} \mathrm{H}\right)$ regions of individual single-domain antibodies each having specific affinity to a particular epitope on an individual algal cell antigen [15]. From the phage-display library containing
$\mathrm{V}_{\mathrm{H}} \mathrm{Hs}$ raised against Chlamydomonas proteins and other immunogenic molecules, a number of phage clones were selected that bound well to the outer surface of live Chlamydomonas cells. Subsequently the $\mathrm{V}_{\mathrm{H}} \mathrm{H}$ gene form each selected phage clone was subcloned into an E. coli overexpression vector. The $\mathrm{V}_{\mathrm{H}} \mathrm{H}$ encoding sequence was cloned upstream and in frame with the coding region for an E-Tag peptide to allow facile detection of the E-tagged/ $\mathrm{V}_{\mathrm{H}} \mathrm{H}$ chimeric protein. Characterization of the individual E-tagged nanobodies overproduced in E. coli using standard enzyme-linked immunosorbent assays (ELISAs) showed that several of these clones bound with moderate to high affinity to proteins and other molecules from cell lysates of Chlamydomonas when these antigens were bound to the walls of wells in polystyrene microtiter plates [15].

Because each standard ELISA assay requires several hours to perform $[14,16,17]$, we sought an equally accurate, but faster, more facile and economic means of determining the affinity with which $\mathrm{V}_{\mathrm{H}} \mathrm{Hs}$ bound to Chlamydomonas cell surface molecules. Given that the initial selection of antibodies with specificity for the Chlamydomonas cell surface had been conducted with live Chlamydomonas cells, we reasoned that it might be possible to develop a modified ELISA procedure in which live cells provided the antigens needed for the assay. Instead of E-tagged sdAbs binding to proteins and other molecules immobilized on polystyrene surfaces to select high affinity $\mathrm{V}_{\mathrm{H}} \mathrm{Hs}$, we hypothesized that we could use a set number of Chlamydomonas cells (providing an excess of cell surface antigens) in individual microfuge tubes containing E-tagged $\mathrm{V}_{\mathrm{H}} \mathrm{H}$ antibodies and then remove non-adhering nanobodies by multiple washing steps involving brief centrifugations and cell suspensions.

In their standard form [14,16-18], ELISAs have proven to be dependable and accurate methods for measuring antibody affinities for specific antigens and for providing estimates of antigen concentrations in samples associated with medical research and practice, agriculture, forensics and industry. An important limitation of the standard ELISA protocol is the time required for binding a target antigen to a solid matrix (generally the wall of wells in a polystyrene microtiter plate) and the multiple washing steps needed to remove unbound antibodies from the wells of the microtiter dish. In the present study, the standard ELISA protocol was recapitulated using a set of microfuge tubes each containing a set number of Chlamydomonas cells and that were inoculated with progressively increasing amounts of E-tagged $\mathrm{V}_{\mathrm{H}} \mathrm{Hs}$. The goal was to mimic corresponding antigen-saturated wells in microtiter plates used for standard ELISA assays. Subsequent steps involving incubation with secondary antibodies conjugated with horseradish peroxidase (HRP), addition of a non-chromogenic substrate and spectrophotometric analysis of the chromogenic product of the HRP reaction 
would be essentially identical to corresponding steps in the standard ELISA procedure.

A search of past literature revealed two early examples of development of live-cell ELISA assays for use with animal cells. The first [19] involved the use of various types of live human cancer and non-cancerous cells to screen for and characterize monoclonal antibodies with specificity for antigens present on the cancer cells but absent from the surface of non-cancerous cells of the same tissue type. The second [20] also utilized a live-cell ELISA to detect antigens specific to different types of cancer cells - in this case, bovine lymphosarcoma cells. More recent examples of live-cell ELISA using mammalian cells have been reviewed by Lourenço and Roque-Barreira [21]. Numerous examples exist of using cells killed by various fixation processes in whole-cell ELISA assays, but, as widely recognized, these methods suffer from the fact that the fixation processes involved often alter the structure and, therefore, the antigenicity of the surface molecules that are the targets of investigation [21]. Our goal in developing a live-cell ELISA analysis of algal cells was to offer the algal and microbiology communities a robust and facile new tool for detecting and roughly quantifying populations of micoorganisms bearing cell surface antigens of targeted interest.

Here we report success in developing a rapid, small-scale, live-cell ELISA assay for algae, demonstrate its equivalence to the standard ELISA procedure, employ it to measure the affinity of various $\mathrm{V}_{\mathrm{H}} \mathrm{Hs}$ to components of the Chlamydomonas cell surface, and show that the high-affinity $\mathrm{V}_{\mathrm{H}} \mathrm{H}$ B11 antibody binds specifically to Chlamydomonas and to other closely related Chlorophycean algae. We also provide visualization of the specificity of binding of $\mathrm{V}_{\mathrm{H}} \mathrm{H} \mathrm{B} 11$ to the Chlamydomonas cell surface by creating and employing $\mathrm{V}_{\mathrm{H}} \mathrm{H} \mathrm{B} 11$ green or red fluorescent proteins that brightly decorate the exterior of live Chlamydomonas cells, but not the surfaces of unrelated algae, during fluorescence microscopy. Finally, we employ the live-cell ELISA techniques and fluorescentlytagged $\mathrm{V}_{\mathrm{H}} \mathrm{H}$ B11 antibodies to demonstrate the presence of wild Chlorophycean relatives of Chlamydomonas in environmental water samples and the isolation by fluorescence activated cell sorting of individual wild relatives of $C$. reinhardtii in those water samples.

\section{Results and discussion}

\section{Analyses of candidate $\mathrm{V}_{\mathrm{H}} \mathrm{H}$ nanobodies with the chlamydomonas live-cell ELISA}

Overproduction of each candidate Chlamydomonas cell surface specific sdAb antibody was achieved by cloning the $\mathrm{V}_{\mathrm{H}} \mathrm{H}$ coding region into the pET32b overexpression vector downstream of coding sequences for thioredoxin $\mathrm{A}$ and $6 \times$ His (for recombinant protein purification) and upstream of the coding region of an E-tag epitope (Figure 1A).
The latter allowed for recognition of the $\mathrm{V}_{\mathrm{H}} \mathrm{H}$ by an E-tag-specific antibody conjugated to horse radish peroxidase (HRP) whose relative enzyme activity served as a measure of the quantity of sdAbs bound to a target antigen in a given assay. Each TrxA/ $6 \times \mathrm{His} / \mathrm{V}_{\mathrm{H}} \mathrm{H} / \mathrm{E}$-tag chimeric protein was tested for its affinity to antigens present (in excess) on the surface of Chlamydomonas cells in the rapid, small-scale, live-cell ELISA procedure described in detail in Methods. The key to the speed of this assay is that it requires less than 30 minutes for the binding of the added antibody to come to equilibrium (Figure 2) and each of two wash steps to remove unbound antibody is accomplished by a quick succession of microfuge centrifugation/cell resuspension steps that, together, consume only 4 minutes. Subsequent incubation with E-tag-specific and HRP conjugated secondary antibody, removal of unbound secondary antibodies by two centrifugation/cell resuspension steps, incubation with nonchromogenic 3,3',5,5' -tetramethylbenzidine (TMB) and measurement of absorbance of the yellow reaction product at $450 \mathrm{~nm}$ all require $30-40$ minutes. Based on experience from multiple experiments, this results in a total assay time of less than 1.5 hours. Standard ELISAs utilize overnight adsorption of antigens to the polystyrene wall of microtiter plate walls with additional manipulations consuming approximately 5 to 8 hours.

\section{Analyses of affinities of $\mathrm{V}_{\mathrm{H}} \mathrm{Hs}$ to Chlamydomonas cell surface molecules}

Three cell surface-specific sdAbs, $\mathrm{V}_{\mathrm{H}} \mathrm{H}$ B11, $\mathrm{V}_{\mathrm{H}} \mathrm{H}$ H10 and $\mathrm{V}_{\mathrm{H}} \mathrm{H} \mathrm{C} 3$ were analyzed with the Chlamydomonas live-cell ELISA protocol. Two nanobodies $\left(\mathrm{V}_{\mathrm{H}} \mathrm{H}\right.$ B11 and $\mathrm{V}_{\mathrm{H}} \mathrm{H}$ H10) displayed $\mathrm{EC}_{50}$ levels of $10 \mathrm{nM}$ or less, with $\mathrm{V}_{\mathrm{H}} \mathrm{H}$ B11 exhibiting the highest affinity $\mathrm{EC}_{50}<1 \mathrm{nM}$ (Figure 3). $\mathrm{V}_{\mathrm{H}} \mathrm{H} \mathrm{C}$, displayed markedly higher $\mathrm{EC}_{50}$ values and only slightly lower than that obtained with a sdAb raised against Clostridium botulinum BoNT/B holotoxin - the $\mathrm{V}_{\mathrm{H}} \mathrm{H}$ used throughout these studies as a negative control (Figure 3). Importantly, results of experiments using the Chlamydomonas live-cell ELISA produced nearly identical $\mathrm{EC}_{50}$ values for $\mathrm{V}_{\mathrm{H}} \mathrm{H}$ B11, $\mathrm{V}_{\mathrm{H}} \mathrm{H} \mathrm{H} 10$, and $\mathrm{V}_{\mathrm{H}} \mathrm{H} C 3$ and $\mathrm{V}_{\mathrm{H}} \mathrm{H}$ BoNT/B (i.e., $0.5 \mathrm{nM}, 10 \mathrm{nM}, 50 \mathrm{nM}$ and $1000 \mathrm{nM}$, respectively) as obtained with a standard ELISA in analyses employed during our original studies [15].

\section{Specificity of $\mathrm{V}_{\mathrm{H}} \mathrm{H}$ B11 for chlorophyceaen algae}

To determine if $\mathrm{V}_{\mathrm{H}} \mathrm{H}$ B11 recognizes all algae, or is restricted to Chlorophycean algae, we performed live-cell ELISA assays on two Heterokonts (aka Stramenopiles), Nannochloropsis oceanica and Thalassiosira pseudonana. When substituted for Chlamydomonas in the live-cell ELISA, none of these algae exhibited affinities above background levels (i.e., affinities exhibited by $\mathrm{V}_{\mathrm{H}} \mathrm{H}$ BoNT/B) (Figure 4). Likewise, $\mathrm{V}_{\mathrm{H}} \mathrm{H} \mathrm{H} 10$ showed affinity only for 


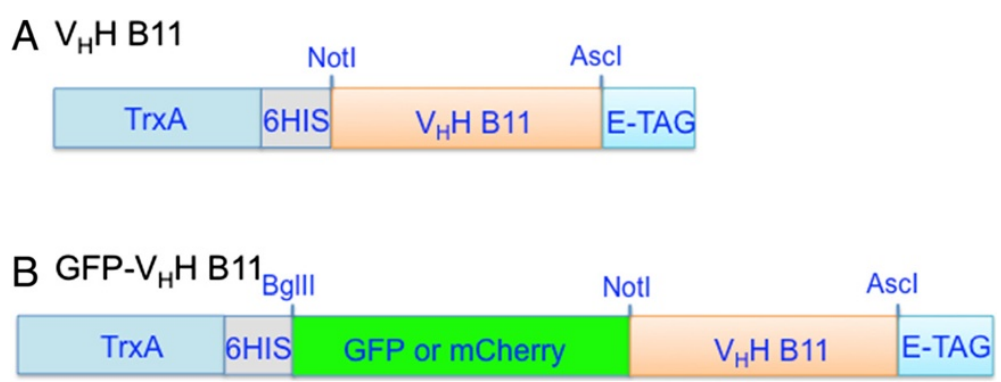

Figure 1 Cassettes for over-expression in $E$. coli of the $\mathrm{V}_{\mathrm{H}} \mathrm{H}$ B11 gene encoding an antibody that recognizes a specific $C$. reinhardtii cell surface antigen. $\mathbf{A}$. $\mathrm{V}_{\mathrm{H}} \mathrm{H}$ B11 cassette for expression of the $\mathrm{V}_{\mathrm{H}} \mathrm{H}$ B11 fusion protein containing the Trx A protein at the $\mathrm{N}$-terminus, an internal $6 \times$ His tag, and an E-tag epitope at the C-terminus. B. GFP-V $\mathrm{H}_{\mathrm{H}} \mathrm{H}$ B11 cassette: identical to $\mathrm{V}_{\mathrm{H}} \mathrm{H}$ B1 1 cassette except for insertion of a GFP or mCherry coding region immediately upstream and in-frame with the $\mathrm{V}_{\mathrm{H}} \mathrm{H}$ coding region.

Chlamydomonas when assayed in an analogous experiment (data not shown). Interestingly, we repeated the livecell ELISAs with the Chlorophycean alga Coccomyxa subellipsoidea and did not observe significant affinity. The genome size of $C$. subellipsoidea that resides in cold polar regions is greatly reduced in size compared to its close Chlorophycean relatives found in temperate climates [22]. One of the key families of Chlorophycean genes lost in its genome are those encoding glycosyl phosphatidyl inositol transamidase that attach cell surface proteins to the plasma membrane [22]. Whether it is the loss of this gene or another gene that may be responsible for the lack of $\mathrm{V}_{\mathrm{H}} \mathrm{H}$ B11 interaction with the cell wall of this Chlorophycean species will need to await future determination of the identity of the antigen to which $\mathrm{V}_{\mathrm{H}} \mathrm{H}$ B11 binds. However, the ability of the $\mathrm{V}_{\mathrm{H}} \mathrm{H}$ B11 antibody to detect differences between cell walls of closely related Chlorophyceans from different environments points to the usefulness of camelid antibodies and monoclonal antibodies in helping to define specific differences in cell

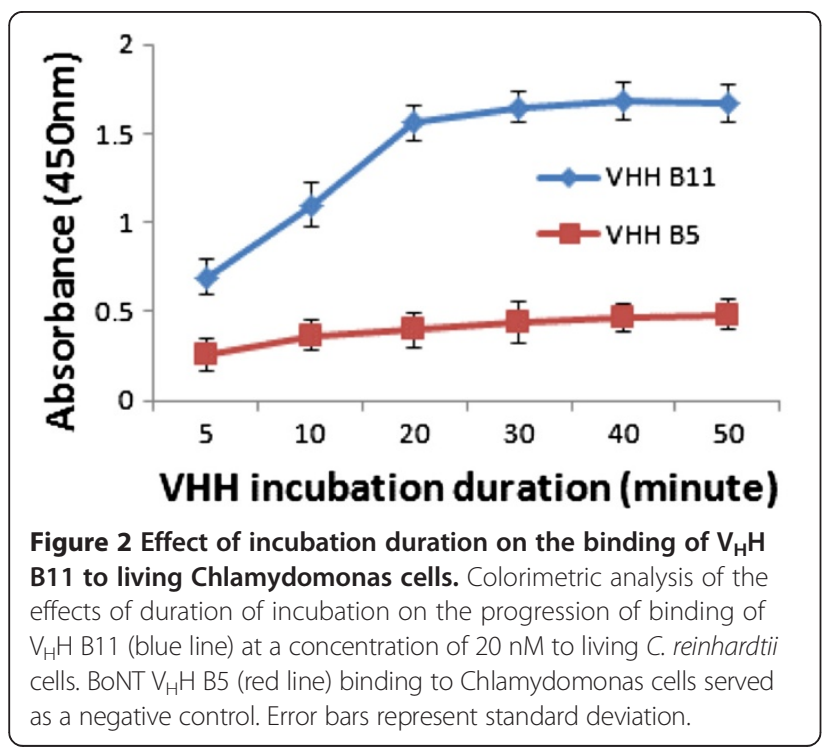

wall composition between different algae and determining how these differences contribute to ecological adaptation.

In regard to specificity of $\mathrm{V}_{\mathrm{H}} \mathrm{H} \mathrm{B} 11$ for Chlorophyceaen algae, it should be noted that in studies described below in which several samples of water from natural environments were tested, a number of the samples containing large numbers and varieties of algae tested negative using either $\mathrm{V}_{\mathrm{H}} \mathrm{H} \mathrm{B11}$ or $\mathrm{V}_{\mathrm{H}} \mathrm{H} \mathrm{H} 10$ - again suggesting strong selectivity of these two sdAbs for the cell surface of Chlamydomonas or Chlamydomonas-related algae and not to distantly related algae.

\section{Saturation of $\mathrm{V}_{\mathrm{H}} \mathrm{H}$ B11 binding with increasing Chlamydomonas cell densities}

During initial experiments to ensure that an excess of cell surface antigens were present in our live-cell ELISAs, a set concentration of $\mathrm{V}_{\mathrm{H}} \mathrm{H}$ B11 $(20 \mathrm{nM})$ was used in each of a

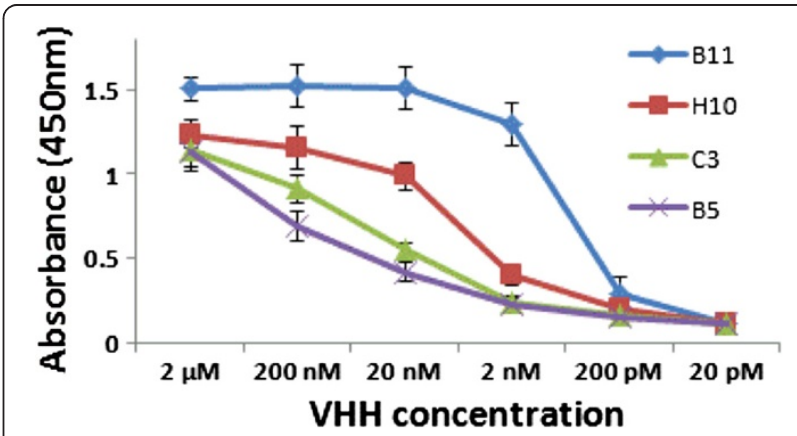

Figure 3 Affinity of cell surface-specific $\mathrm{V}_{\mathrm{H}} \mathrm{Hs}$ to living C. reinhardtii cells. Live-cell ELISA analyses comparing binding affinities to $C$. reinhardtii cells of various E-tag $V_{H} H s$ (B11, blue line; $\mathrm{H} 10$, red line; $\mathrm{C} 3$, green line); and $\mathrm{V}_{\mathrm{H}} \mathrm{H} \mathrm{B} 5$ (a $\mathrm{V}_{\mathrm{H}} \mathrm{H}$ binding specifically to a Clostridium botulinum BoNT/B holotoxin; negative control) purple line. Cells were incubated with serial dilutions of $\mathrm{E}$-tag $\mathrm{V}_{\mathrm{H}} \mathrm{Hs}$ at concentrations from $2 \mu \mathrm{M}$ to $20 \mathrm{pM}$. E-tag $\mathrm{V}_{\mathrm{H}} \mathrm{H}$ nanobodies attached to Chlamydomonas cells were detected using a HRP conjugated E-tag antibody that reacted with TMB (3,3',5,' ${ }^{\prime}$-tetramethylbenzidine) to measure amounts of $\mathrm{V}_{\mathrm{H}} \mathrm{H}$ bound to cell surface antigens. Error bars represent standard deviation. 


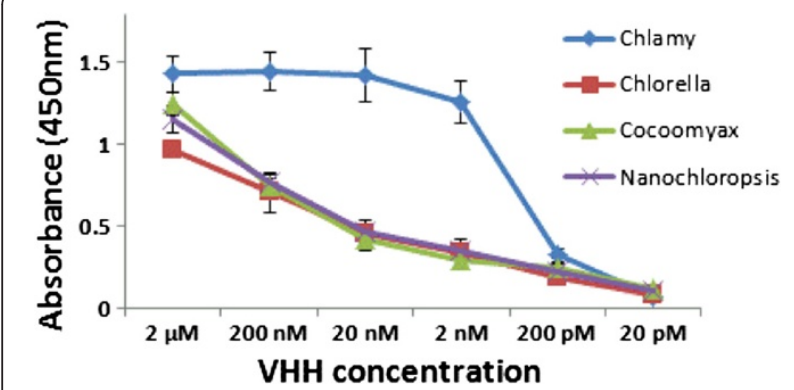

Figure 4 Affinity of $\mathrm{V}_{\mathrm{H}} \mathrm{H}$ B11 to Chlamydomonas and other algal cells. Live-cell ELISA analyses comparing the binding affinity of $\mathrm{V}_{\mathrm{H}} \mathrm{H} \mathrm{B} 11$ to living Chlamydomonas reinhardtii (cc124) cells (blue line) and other living algae cells (Chlorella, red line; Nannochloropsis, purple line; Coccomyxa, green line). Error bars represent standard deviation.

set of microfuge tubes into which progressively increasing concentrations of live Chlamydomonas cells were added (i.e., from $2.5 \times 10^{2}$ cell/ $0.5 \mathrm{~mL}$ to $2.5 \times 10^{7}$ cells $/ 0.5 \mathrm{~mL}$ ). The results of this experiment indicated that slightly less than $10^{6}$ cells $/ 0.5 \mathrm{~mL}$ were needed to cause all $\mathrm{V}_{\mathrm{H}} \mathrm{H}$ B11 molecules to be associated with cell surface antigens (Figure 5). Thus, for subsequent live-cell assays, Chlamydomonas cell concentrations of approximately $10^{6}$ cells $/ 0.5 \mathrm{~mL}$ were employed.

\section{Modification of the live-cell ELISA for detection of algae in environmental samples}

Using a modification of our new live-cell ELISA protocol we also developed a rapid, small-scale method for obtaining rough estimates of populations of Chlamydomonas-related cells (i.e., those displaying the surface antigen to which $\mathrm{V}_{\mathrm{H}} \mathrm{H} \mathrm{B} 1$ binds) in samplings of algae from natural settings. In these assays, the algal samples were concentrated by centrifugation and resuspended in a mixture of $\mathrm{V}_{\mathrm{H}} \mathrm{H}$

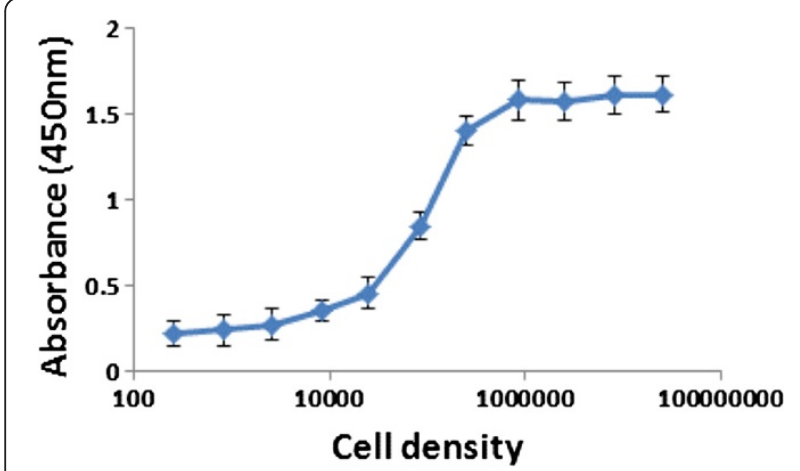

Figure 5 Effect of cell density on the binding of $\mathrm{V}_{\mathrm{H}} \mathrm{H} \mathrm{B} 11$ to living Chlamydomonas cells. Colorimetric analysis the effects of cell density on the binding of $\mathrm{V}_{\mathrm{H}} \mathrm{H}$ B11 (blue line) to living C. reinhardtii cells. Cells at different densities were incubated with $\mathrm{V}_{\mathrm{H}} \mathrm{H} \mathrm{B} 11$ at a concentration of $20 \mathrm{nM}$. Error bars represent standard deviation.
B11 and reagents to a cell density the same as used in the Chlamydomonas live-cell ELISA procedure. After two washings, cells were subjected to the prescribed protocols (see descriptions above and Methods) for incubation with secondary HRP conjugated E-tag antisera and measurements of enzyme activity. Evaluation using the live-cell ELISA analysis of ten independent environmental water samples allowed rapid identification of three of these samples as containing appreciable numbers of algae capable of binding $\mathrm{V}_{\mathrm{H}} \mathrm{H}$ B11 (Figure 6).

\section{GFP/mCherry $\mathrm{V}_{\mathrm{H}} \mathrm{H}$ B11 chimeras and their use in} identifying novel $C$. reinhardtii-related unicellular chlorophycean aglae

Further analyses of algae in environmental samples took advantage of our earlier described [15] coupling of the coding region of the green fluorescent protein (GFP) to the 5 ' terminus of the $\mathrm{V}_{\mathrm{H}} \mathrm{H}$ B11 coding region (Figure $1 \mathrm{~B}$ ) to produce a GFP/ $\mathrm{V}_{\mathrm{H}} \mathrm{H}$ B11 chimera. This chimera could then be used to demonstrate specific binding of the antibody to the cell surface of Chlamydomonas using confocal microscopy (Figure 7A). Incubation of Chlamydomonas with GFP $\mathrm{V}_{\mathrm{H}} \mathrm{H}$ B5 anti-botulinum toxin nanobody (negative control) produced no fluorescently stained cells (Figure 7D). Incubation of Nannochloropsis oceanica, Coccomyxa subellipsoidea, and Thalassiosira pseudonana with the GFP/V $\mathrm{V}_{\mathrm{H}} \mathrm{H}$ B11 produced no GFP signal (data not shown).

To search for C. reinhardtii or closely related Chlorophyceae species in the water samples discussed above, we mixed algae in the samples with an mCherry/ $\mathrm{V}_{\mathrm{H}} \mathrm{H}$ B11 chimera prior to examination by confocal microscopy. While seven samples failed to yield cells capable of binding the $\mathrm{mCherry} / \mathrm{V}_{\mathrm{H}} \mathrm{H}$ B11 nanobody, three water samples displaying the highest ELISA values (Figure 6: \#5, \#6 and \#9) contained a subpopulation of algal cells capable of binding with $\mathrm{mCherry} / \mathrm{V}_{\mathrm{H}} \mathrm{H}$ B11. When compared with binding of $\mathrm{mCherry} / \mathrm{V}_{\mathrm{H}} \mathrm{H}$ B11 to $C$. reinhardtii cell walls

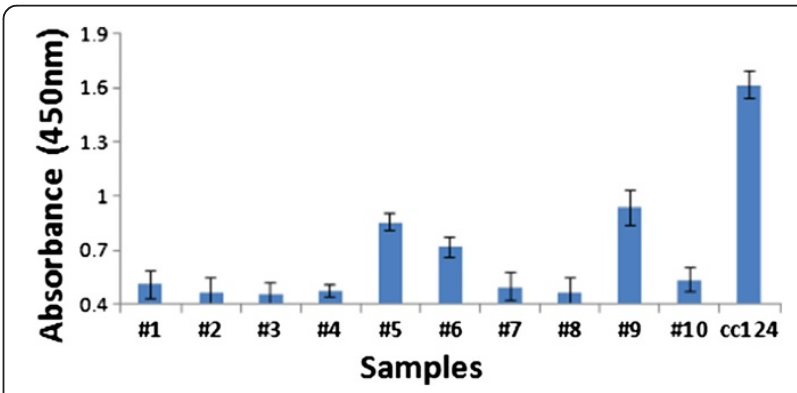

Figure 6 ELISA test for binding of $\mathrm{V}_{\mathrm{H}} \mathrm{H} \mathrm{B} 11$ to Chlamydomonas and to other algal cells in pond water samples. Colorimetric analyses comparing the binding affinity of $\mathrm{V}_{\mathrm{H}} \mathrm{H} \mathrm{B} 11$ to living C. reinhardtii (cc124) cells and to mixtures of other living algae in 10 independent pond water samples. Error bars represent standard deviation. 

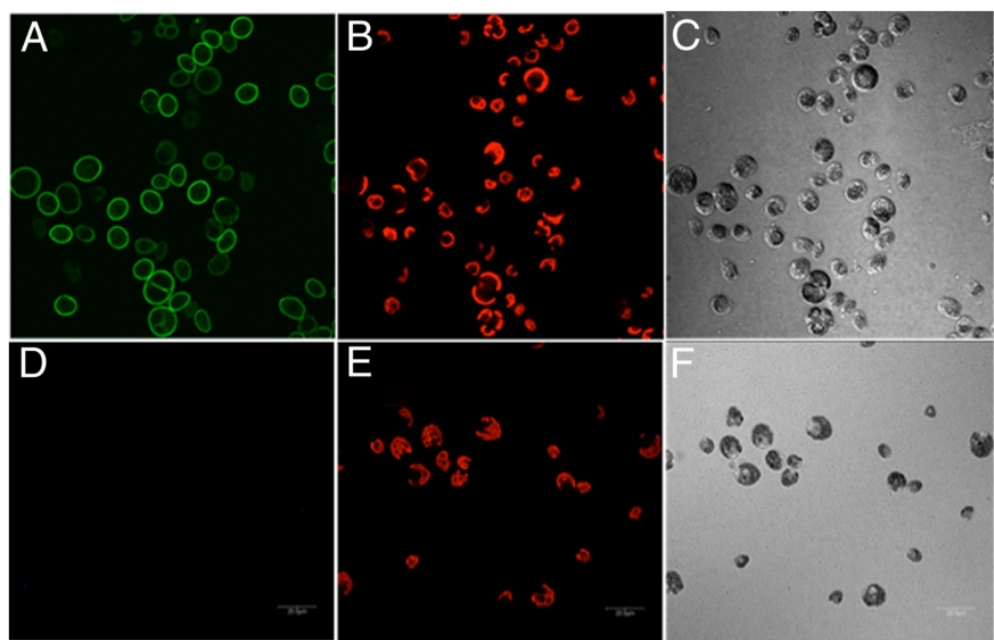

Figure 7 Confocal microscope images of wild type $C$. reinhardtii (cc124) incubated with the GFP-V $\mathrm{V}_{\mathrm{H}} \mathrm{B} 11$ chimeric nanobody. A) Cells detected in the GFP fluorescence channel displaying specific staining of the cell walls. D) Cells incubated with a GFP-V $V_{H} H$ B5 (negative control) showing no fluorescence. A and D: GFP fluorescence channel, B and E: chloroplast auto-fluorescence channel; C and F: phase contrast images of cells.

(Figure 8), two algae bound to a nearly equal extent (Figures 9 and 10), while the third bound to a distinctly lower extent (Figure 11).

As further demonstration of the utility of the mCherry/ $\mathrm{V}_{\mathrm{H}} \mathrm{H}$ B11 nanobodies, we subjected cells from environmental water sample \#9 to fluorescence activated cell sorting after incubation with mCherry $/ \mathrm{V}_{\mathrm{H}} \mathrm{H}$ B1. In so doing, we were able to capture single cells (e.g., cell isolate \#9-2i; Figure 12) to which the mCherry-labeled nanobody was bound and culture them on solid medium in preparation for taxonomic classification based on DNA sequencing of their $18 \mathrm{~S}$ ribosomal RNA genes (described below).

\section{Species identification of chlorophycean relatives that} react with the $\mathrm{V}_{\mathrm{H}} \mathrm{H}$ B11 sdAb

Having identified three strains that strongly react with $\mathrm{V}_{\mathrm{H}} \mathrm{H}$ B11 in environmental water samples, we identified the algae by sequencing their ribosomal internal transcribed spacer regions (ITS1 and ITS2) [23]. First, to provide additional insurance that each of the three environmental isolates were axenic, we performed multiple rounds of antibiotic washing, dilution, and plating for single clones on tris-phosphate (TP) plates. Three or more decontaminated clones of each isolate were pooled prior to ITS analysis.

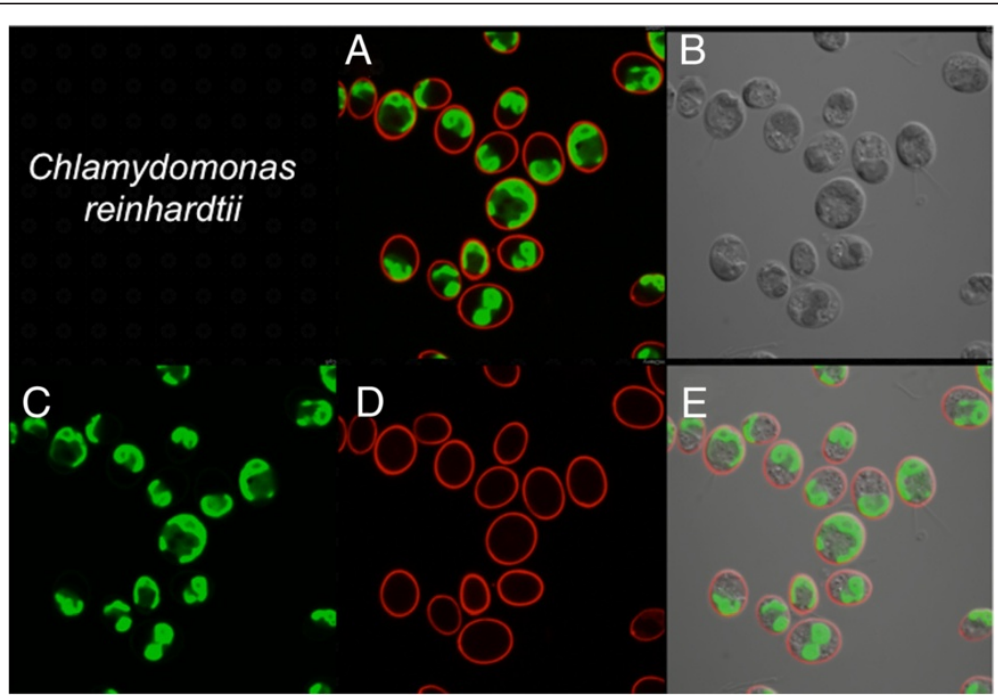

Figure 8 Confocal microscope images of $C$. reinhardtii incubated with mCherry $V_{H} H$ B11 chimeric antibody. A) Merged image from $C$ (chlorophyll fluorescence; pseudo green) and $\mathbf{D}$ (mCherry red fluorescence). B) Phase contrast image of cells. E) Merged images from B, C and $\mathbf{D}$. 


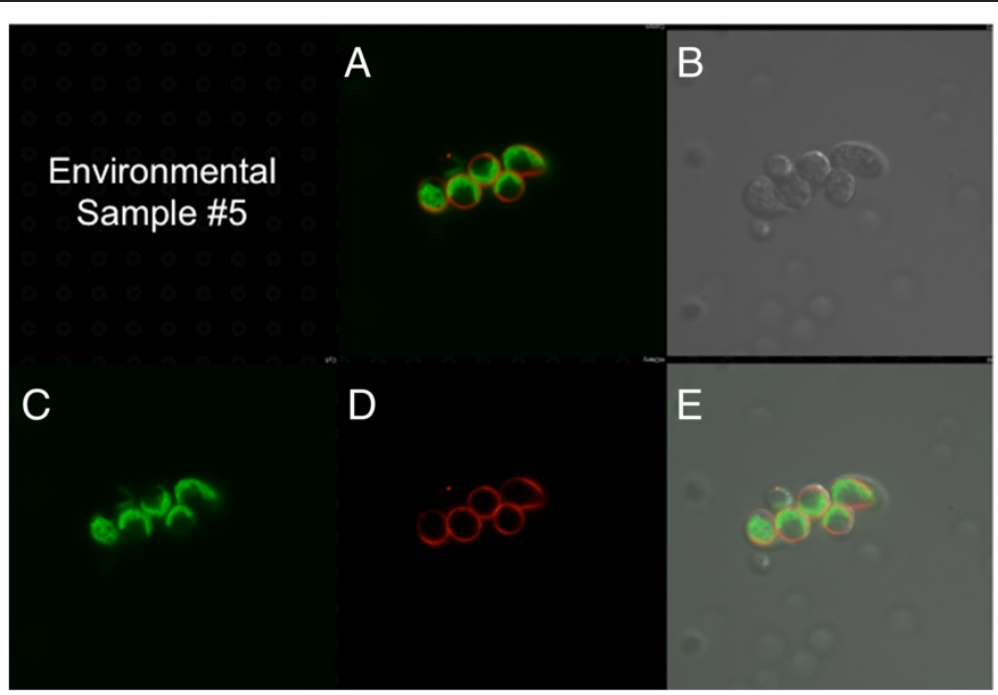

Figure 9 Confocal microscope images of sample \#5 cells incubated with mCherry $V_{H} H$ B11 chimeric nanobody. A) Merged image from $C$ (chlorophyll fluorescence; pseudo green) and $\mathbf{D}$ (mCherry red fluorescence). B) Phase contrast image of cells. E) Merged images from $\mathbf{B}, \mathbf{C}$ and $\mathbf{D}$.

After amplification and sequencing of the ITS1 and ITS2 regions and phylogenetic analysis, isolate 2i phylogenetically clusters with several Desmodesmus species, where its ITS2 sequence demonstrate it is D. pleiomorphus (Figure 13). Interestingly, this is one of the few unicellular biflagellate species of $D$. pleiomorphus that has been described [24]. Likewise, strain $2 \mathrm{~h}$ phylogenetically clusters with Scenedesmus obliquus another taxonomically distinct group of unicellular bi-flagellate algae [25,26]. Interestingly, the Scenedesmus genus was originally morphologically characterized as being multicellular sheets of cells [27]. However with improved molecular phylogenetic techniques, many unicellular bi-flagellates previously placed in other groups have been transferred to Scenedesmus and its Desmodesmus sub-group [26].

Strain $2 \mathrm{f}$ is unique because it phylogenetically clusters with a group of environmental isolates found to be in close association with Bryophytes (Figure 9). Member of its clade include Coelastrella and Scenedesmus [26], as well as several mis-identified unicellular bi-flagellate algae (attributed as C. moewussi, though this group is far removed from the Chlamydomonacales (Figure 13 and Additional file 1: Figures S1 and S2). Because its closest relative has been positively identified as Coelastrealla, we currently classify this strain as such. Interestingly, taking a broad view of the phylogeny of these three novel

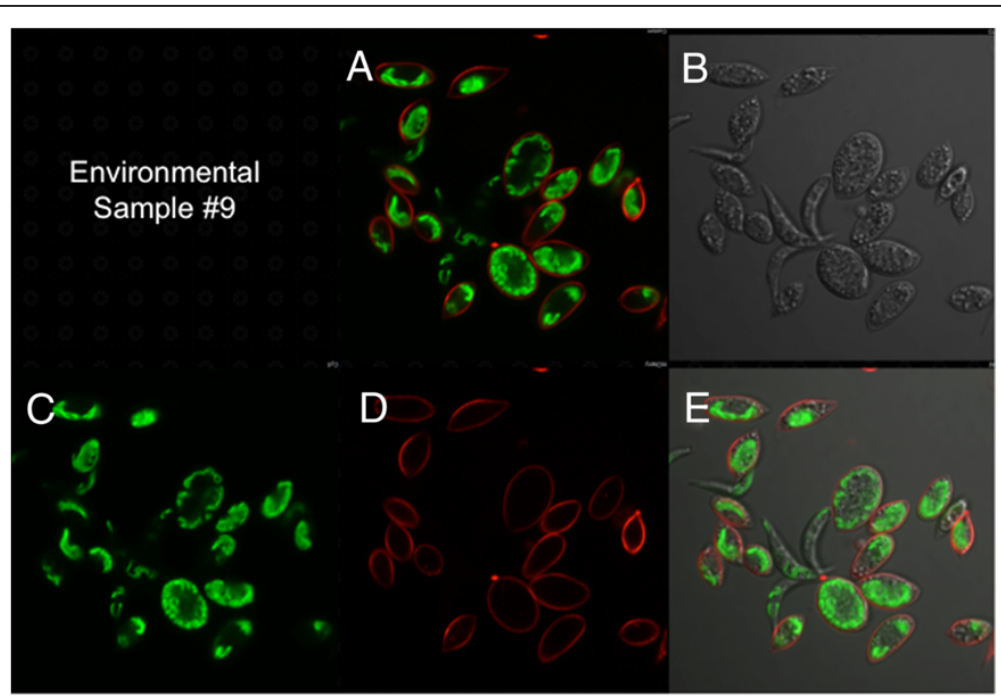

Figure 10 Confocal microscope images of sample \# 9 cells incubated with mCherry $\mathrm{V}_{\mathrm{H}} \mathrm{H}$ B11 chimeric nanobody. A) Merged image from C (chlorophyll fluorescence; pseudo green) and $\mathbf{D}$ (mCherry red fluorescence). B) Phase contrast image of cells. E) Merged images from B, C and $\mathbf{D}$. 


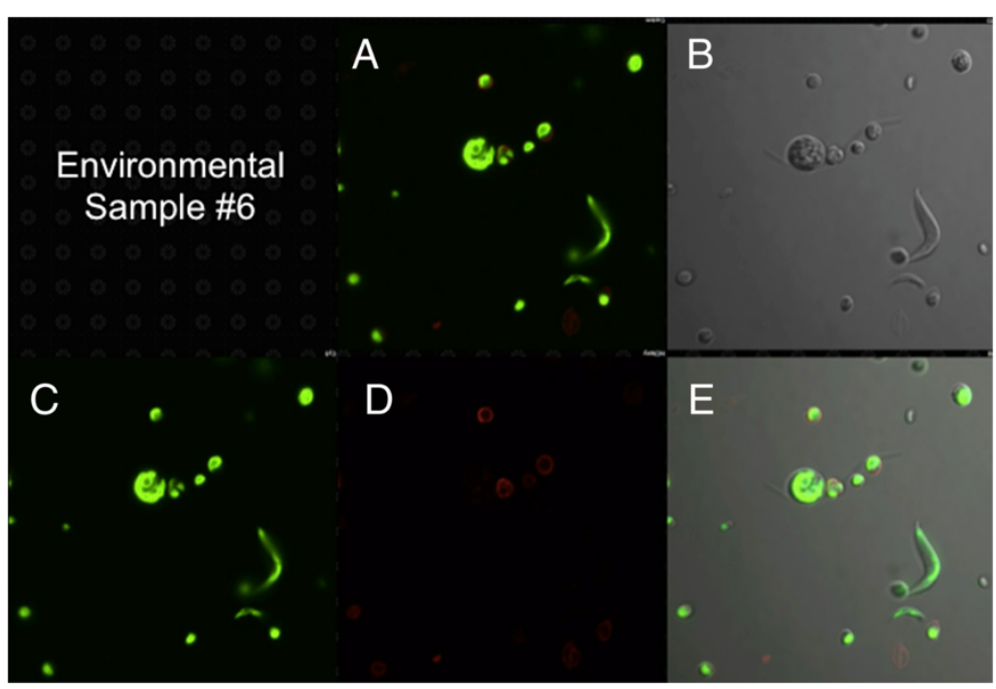

Figure 11 Confocal microscope images of sample \#6 cells incubated with mCherry $\mathrm{V}_{\mathrm{H}} \mathrm{H}$ B11 chimeric nanobody. A) Merged image from C (chlorophyll fluorescence; pseudo green) and $\mathbf{D}$ (mCherry red fluorescence). B) Phase contrast image of cells. E) Merged images from $\mathbf{B}, \mathbf{C}$ and $\mathbf{D}$.

environmental isolates demonstrates that $\mathrm{V}_{\mathrm{H}} \mathrm{H}$ B11 broadly binds to cell-wall proteins found in unicellular Chlorophycean algae (Additional file 1: Figures S1 and S2). This demonstrates the broad usefulness of this antibody as a tool for identifying novel unicellular algae, but also suggests broad conservation of the cell wall amongst distantly related unicellular Chlorophycean algae.

DNA sequences of $18 \mathrm{~S}$ ribosomal RNA gene ITS1 and ITS2 regions used in these studies for construction of phylogenetic maps have been deposited in GenBank and accession numbers are listed in Additional file 1: Table S1.
Future studies will focus on use of the $\mathrm{V}_{\mathrm{H}} \mathrm{H}$ B11 nanobody to aid in the purification and molecular characterization of the target antigen from Chlamydomonas and the three different algal strains described here. The long-term goal will be to use a similar approach for isolation and characterization of additional cell wall/cell surface components that will allow not only comparisons of cell wall composition between related algae but also between cell walls of land plants and the algae from which they were evolutionarily derived.

A significant advantage of the live-cell ELISA procedure is that it allows interaction of $\mathrm{V}_{\mathrm{H}} \mathrm{Hs}$ with cell

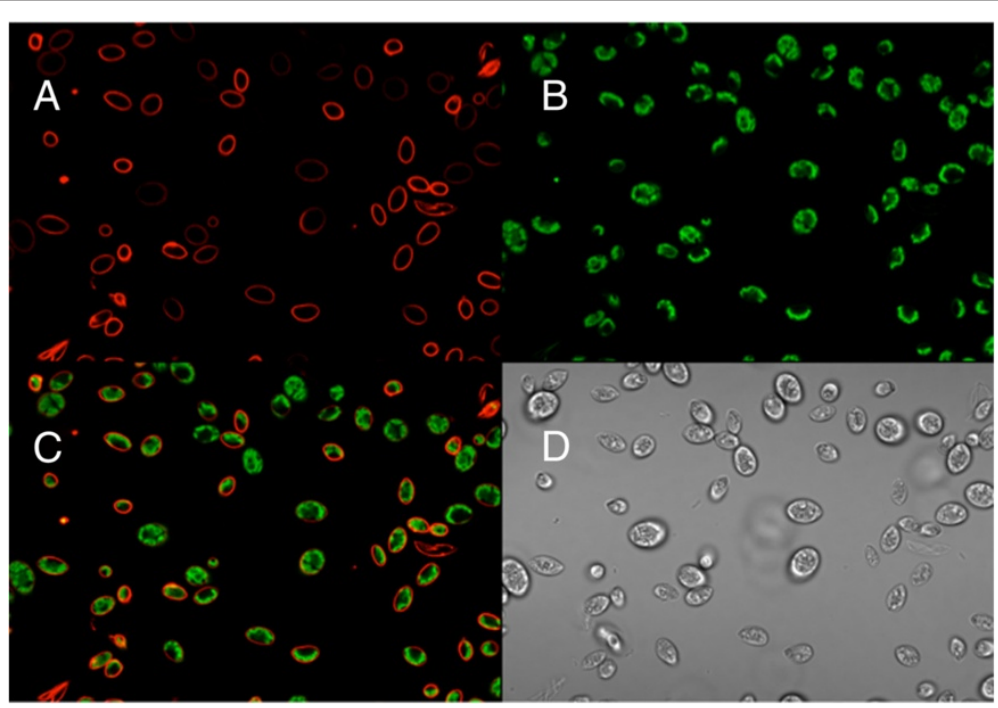

Figure 12 Confocal microscope images of a presumed wild relative of Chlamydomonas (\#9-2i) isolated from environmental sample \#9 by flow cytometry after staining with $\mathrm{mCherry/VHH} \mathrm{B11} \mathrm{nanobody.} \mathrm{Single} \mathrm{cells} \mathrm{separated} \mathrm{by} \mathrm{flow} \mathrm{cytometry} \mathrm{were} \mathrm{cultured} \mathrm{on} \mathrm{solid} \mathrm{TAP}$ medium prior to resuspention in liquid medium and confocal microscopic analysis. A) mCherry staining of cell walls. B) Chlorophyll fluorescence (pseudo green color). C) Merged images from B and C. D) Phase contrast image of cells. 


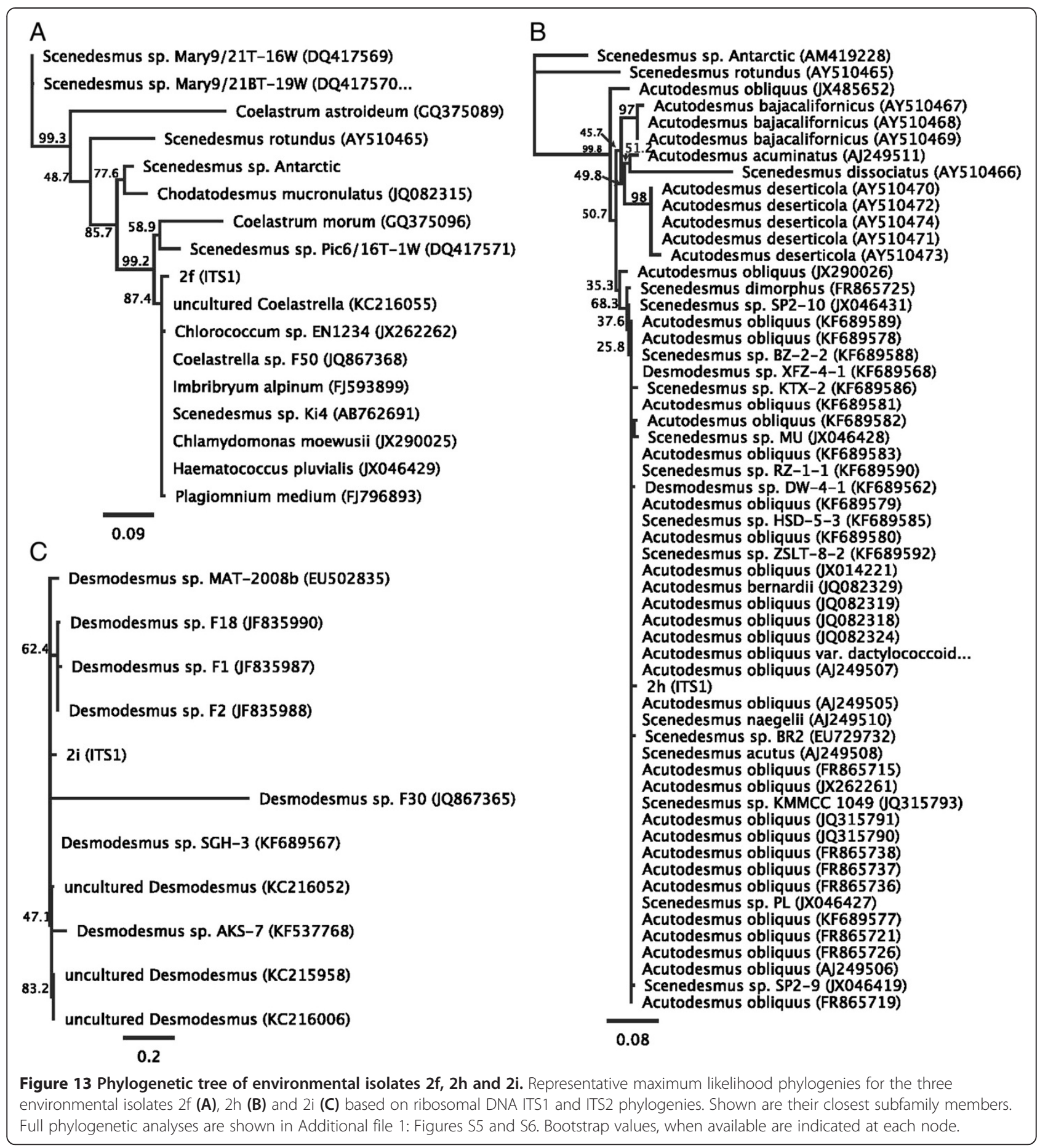

surface antigens in their native state. This represents a significant improvement compared to standard ELISA procedures in which antigens are adsorbed to the polystyrene surface of microtiter plate wells, a step that often results in protein denaturation. A search of the literature has revealed no previous use of standard ELISAs or live-cell ELISAs to identify algae with shared cell wall components. Thus, the present study provides the research community with a facile new means for accomplishing this task. There are obvious limitations to the methods as presently described. For example, not all cell surface components will posses sufficient antigenicity to elicit a strong antibody response in immunized animals and, even if tight binding antibodies are obtained, there 
may be algae in which the target antigen is produced in very low quantities or may produce target antigens that are buried or masked within the cell wall.

\section{Conclusions}

Together, the experimental results presented here demonstrate the ability of $\mathrm{V}_{\mathrm{H}} \mathrm{H} \mathrm{B} 11$ and mCherry-tagged $\mathrm{V}_{\mathrm{H}} \mathrm{H}$ B11 to allow detection, isolation and identification of algal cells from various ecosystems that share cell wall and cell surface components with Chlamydomonas. These results point the way to future research aimed at discovery of additional cell wall/cell surface components shared by Chlorophycean algae and to the initiation of detailed biochemical, molecular and genetic studies of these molecules. More generally, use of the live-cell ELISA assay described here and the production of highly specific antibodies, such as the $\mathrm{V}_{\mathrm{H}} \mathrm{Hs}$ employed in the present study, have the potential to greatly facilitate future searches of the natural environment for particular species of algae and other microorganisms of interest to a broad range of laboratories around the world.

\section{Methods}

\section{Chemicals and biologicals}

E-Tag Antibody (HRP conjugated) was purchased from Bethyl Laboratories Inc. (Catalog No. A190-132P). TMB (3,3',5,5' -Tetramethylbenzidine (Liquid Substrate System for ELISA) was provided by Sigma (Catalog No. T0440). Protein concentrations were measured using a Bio-Rad Protein Assay (Catalog No. 500-0005).

\section{Environmental water sample preparation}

Environmental water samples of $10 \mathrm{~mL}$ each were collected from the Holmes Lake area and other public and private ponds in Lancaster county, and Lincoln, NE. Collected cells were maintained in TP medium (TAP medium lacking acetate) in light under $3 \% \mathrm{CO}_{2}$ with shaking at 100 RPM. ELISA analyses and fluorescence confocal microscopy were performed as described below. Single algal cells binding the GFP$\mathrm{V}_{\mathrm{H}} \mathrm{H}$ B11 were isolated using a BD FACS Aria flow cytometer.

\section{$\mathrm{V}_{\mathrm{H}} \mathrm{H}$ expression vectors}

Three surface binding $\mathrm{V}_{\mathrm{H}} \mathrm{H}$ cDNA clones [15] in JSC phagemid vectors (GenBank Accession Number: EU109715) were cut with NotI/AscI and DNA fragments were migrated into a pET32b backbone pre-engineered to contain an E-Tag and NotI/AscI cloning sites. The resulting $\mathrm{V}_{\mathrm{H}} \mathrm{H}$ protein products contained a N-terminal thioredoxin ( $\operatorname{Trx} \mathrm{A}$ ) fusion partner, an internal $6 \times \mathrm{His}$ tag, and a C-terminal E-tag. Using these expression vectors as backbone, a GFP or mCherry coding region was fused directly to the $\mathrm{N}$-terminus of the $\mathrm{V}_{\mathrm{H}} \mathrm{H}$ coding region to allow production of fluorescent versions of $\mathrm{V}_{\mathrm{H}} \mathrm{Hs}$ for confocal microscopy assays. To accomplish this, a GFP coding region (a synthetic construct encoding monomeric GFP fluorescent protein gene, Accession Number AAC53663) and a mCherry coding region (a synthetic construct encoding monomeric mCherry fluorescent protein gene, Accession Number AY678264) were inserted at BglII-NotI cutting sites in the $\mathrm{V}_{\mathrm{H}} \mathrm{H}$ expression vectors, in such a way that the resulting $\mathrm{V}_{\mathrm{H}} \mathrm{H}$ fluorescence protein products contained a $\mathrm{N}$-terminal thioredoxin ( $\operatorname{Trx} \mathrm{A}$ ) fusion partner, an internal $6 \times$ His tag followed by a GFP or a mCherry fluorescence protein and a C-terminal E-tag.

\section{Expression and purification of $\mathrm{V}_{\mathrm{H}} \mathrm{H}$ fusion proteins}

Escherichia coli strain BL21(DE3) bearing the $\mathrm{V}_{\mathrm{H}} \mathrm{H}$ fusion gene in pET32b was grown in $\mathrm{LB}$ media at $37^{\circ} \mathrm{C}$ with shaking until reaching an $\mathrm{OD}_{600}$ of 0.6. Expression of the recombinant protein was induced with $1 \mathrm{mM}$ IPTG at $20^{\circ} \mathrm{C}$ for $20 \mathrm{hrs}$. The bacterial cells were harvested by centrifugation at $5000 \times g$ for $15 \mathrm{~min}$ and resuspended in ice-cold lysis buffer [50 $\mathrm{mM}$ sodium phosphate (pH 8.0), $300 \mathrm{mM} \mathrm{NaCl}, 10 \mathrm{mM}$ imidazole, $1 \mathrm{mM}$ PMSF, and Protease Inhibitor Cocktail for use with bacterial cell extracts (Sigma, P8465)]. The re-suspended cells were treated with lysozyme at the concentration of $1 \mathrm{mg} / \mathrm{mL}$ for one-half hour before sonication at $4^{\circ} \mathrm{C}$ with a Sonics \& Materials sonicator, Model VCX 600 (Sonics and Materials Inc, Danbury, CT, USA) at an amplitude of $30 \%$ in $9.9 \mathrm{~s}$ bursts with $9.9 \mathrm{~s}$ resting periods for $15 \mathrm{~min}$. The sonicated cell lysate was clarified by centrifugation at $20,000 \times g$. The supernatant was loaded onto a $\mathrm{Ni}^{2+}-\mathrm{NTA}$ metal-affinity resin and washed with buffer containing $50 \mathrm{mM}$ sodium phosphate (pH 8.0), $300 \mathrm{mM} \mathrm{NaCl}$ and $20 \mathrm{mM}$ imidazole. Bound protein was released with elution buffer containing $50 \mathrm{mM}$ sodium phosphate ( $\mathrm{pH} 8.0$ ), $120 \mathrm{mM} \mathrm{NaCl}$ and $250 \mathrm{mM}$ imidazole. The eluted protein was dialyzed against $50 \mathrm{mM}$ Tris $(\mathrm{pH} 7.5)$. The final protein concentration was determined using Bradford's reagent (Bio-Rad, Hercules, CA). Purity of the $\mathrm{V}_{\mathrm{H}} \mathrm{H}$ fusion protein was determined by analysis on an overloaded, Coomassie-stained, SDS-PAGE. Only freshly prepared $\mathrm{V}_{\mathrm{H}} \mathrm{H}$ fusion proteins were used for affinity assays.

\section{Live-cell $\mathrm{V}_{\mathrm{H}} \mathrm{H}$ ELISA}

For live-cell $\mathrm{V}_{\mathrm{H}} \mathrm{H}$ ELISAs, $100 \mu \mathrm{L}$ of a $C$. reinhardtii (CC124) culture or other algae cells at a density of approximately $10^{7}$ cells $/ \mathrm{mL}$ was transferred into a $1.5 \mathrm{~mL}$ centrifuge tube, centrifuged at $6000 \times \mathrm{g}$ for $2 \mathrm{~min}$, and resuspend in $500 \mu \mathrm{L}$ TAP medium containing $1 \%$ dry milk (filter sterilized). Cells were shaken slowly under light for $5 \mathrm{~min}$ before addition of $\mathrm{V}_{\mathrm{H}} \mathrm{H}$ at the desired final concentration. As controls, similar incubations with live Chlamydomonas cells were conducted in the presence of a $\mathrm{V}_{\mathrm{H}} \mathrm{H}$ raised against Clostridium botulinum 
(BoNT $\mathrm{V}_{\mathrm{H}} \mathrm{H}$ B5; 9). After incubation of the $\mathrm{V}_{\mathrm{H}} \mathrm{H}$ protein with cells for $25 \mathrm{~min}$ under light, cells were collected by centrifugation, washed twice in $700 \mu \mathrm{L}$ TAP medium and transferred to $500 \mu \mathrm{L}$ TAP medium containing the equivalent of $0.025 \mu \mathrm{L}$ of undiluted E-Tag antibody. Cells were incubated in the light with the E-Tag antibody for $25 \mathrm{~min}$ as described above. After centrifugation and two washes with TAP medium, cells were re-suspend in $100 \mu \mathrm{L}$ TMB and mixed well. After 5 minutes, $100 \mu \mathrm{L}$ of $1 \mathrm{~N} \mathrm{HCI}$ was added to terminate the reaction. A buffer control was made by mixing $100 \mu \mathrm{L}$ each $1 \mathrm{~N} \mathrm{HCI}$ and TMB. Cells were pelleted by centrifugation at $13,000 \times g$ for $1 \mathrm{~min}$ and the absorbance of the supernatant was measured at a wavelength of $450 \mathrm{~nm}$.

\section{Fluorescence confocal microscopy}

For analysis of binding of GFP- or mCherry-tagged nanobodies to the cell surface of $C$. reinhardtii and other algae using confocal microscopy, cells in $0.5 \mathrm{~mL}$ of cell culture at saturation density were collected by centrifugation at $5000 \times g$ for 2 minutes in a $1.5 \mathrm{~mL}$ centrifuge tube. Cell pellets were re-suspended in $0.5 \mathrm{~mL}$ TAP medium containing $1 \%$ non-fat dry milk and then shaken for $15 \mathrm{~min}$ in light. Cells were washed twice with TAP medium and re-suspended in $0.5 \mathrm{~mL}$ TAP medium containing $1 \%$ non-fat dry milk, followed by the addition of chimeric mCherry or GFP $\mathrm{V}_{\mathrm{H}} \mathrm{H}$ B11 nanobody to the desired final concentration, typically $30 \mathrm{nM}$. Fluorescence BoNT $\mathrm{V}_{\mathrm{H}} \mathrm{H}$ B5 served as negative control. After shaking for $30 \mathrm{~min}$ in light, cells were washed twice with TAP medium. Cells were then examined by confocal fluorescence microscopy using a Nikon ECLIPSE 90i system at $1000 \times$ magnification. The excitation wavelength was set at $561.5 \mathrm{~nm}$ and the emission wavelength at $570-620 \mathrm{~nm}$ for mCherry fluorescence, $448 \mathrm{~nm}$ and $500-550 \mathrm{~nm}$ for GFP fluorescence and at $641 \mathrm{~nm}$ and 662-737 $\mathrm{nm}$ for chlorophyll auto-fluorescence to ensure no cross talk between different fluorescence channels.

\section{Taxonomic identification of environmental isolates}

Environmental samples were initially maintained xenically, however, to taxonomically classify them, they were made axenic by ten alternating rounds of washing with sterile TP medium supplemented with $800 \mu \mathrm{g} / \mathrm{mL}$ carbenecillin, $5 \mu \mathrm{g} / \mathrm{mL}$ ciprofloxacin, $50 \mu \mathrm{g} / \mathrm{mL}$ chloramphenicol, $5 \mu \mathrm{g} / \mathrm{mL}$ trimethoprim and $0.1 \%$ tween-20, followed by centrifugation at $100 \mathrm{~g}$ for 2 minutes. After centrifugation, samples were top illuminated with $20 \mu \mathrm{E}$ of light for 5 minutes, then the supernatant containing algae was removed and centrifuged at $1000 \mathrm{~g}$ for 5 minutes, the supernatant was discarded, while pelleted algal cells were collected. After washing and differential centrifugation, algal cells were serially diluted and plated on TP agar plates. Single colonies were picked into fresh media and tested for the presence of contaminating organisms by examination with microscopy and by replica plating on TAP agar supplemented with $5 \%$ yeast extract. Three independent clones were randomly chosen for taxonomic identification.

Genomic DNA was prepared from each independent clone with a plant specific spin column DNA preparation kit (Omega Biotek Plant EZNA). The ITS1 and ITS2 ribosomal spacer regions were independently amplified in two independent PCR reactions with Phusion DNA polymerase using primers for ITS1 [GGGATCCGTTTCCGTAGGTG AACCTGC (forward) and GCTGCGTTCTTCAGCGAT (reverse)] and for ITS2 [GGGATCCATATGCTTAAGTTC AGCGGGT (forward) and GCATCGATGAAGAACGCA GC (reverse)]. PCR products of the expected size were pooled and sub-cloned (Thermo pJECT), and three independent clones were sequenced. For all three strains, each of the independent algal and PCR product clones produced identical sequences. The ITS1 and ITS2 sequences were used to search the NCBI database by BLAST for closely related sequences. These sequences were aligned by MUSCLE [28]. Phylogenies were determined with a HKY85 substitution model using maximum likelihood in PhyML [29] with 100 rounds of bootstrap support.

\section{Additional file}

Additional file 1: Supplementary Figures and Table. Figure S1. Phylogenetic tree of environmental isolates $2 \mathrm{f}, 2 \mathrm{~h}$ and $2 \mathrm{i}$ based on ITS 1 ribosomal DNA sequence comparisons. Figure S2. Phylogenetic tree of environmental isolates $2 \mathrm{f}$, $2 \mathrm{~h}$ and $2 \mathrm{i}$ based on ITS 2 ribosomal DNA sequence comparisons. Table S1. DNA sequences used for phylogenetic analyses.

\section{Competing interests}

The authors declare that they have no competing interests.

\section{Authors' contributions}

WJ, JR, BO, GO and DW conceived and designed studies, JW, SO and JR performed experiments, JW, JR, BO, GO and DW analyzed and interpreted data, WJ, JR, BO, GO and DW wrote the manuscript. All authors read and approved the final manuscript.

\section{Acknowledgements}

The authors thank Drs. Jim Van Etten for supplying environmental water samples and Christian Elowsky for assistance with confocal microscopy. This work was funded, in part, by grants from NSF (grants number MCB-0952533 to DPW and EPSCOR-1004094 to DPW and GAO) and DOE (DOE award number DE-EE0001052 and DOE CAB-COMM award number DE-EE0003373 to DPW and $\mathrm{GAO})$. DNA sequences from this study have been deposited in GenBank.

\section{Author details}

${ }^{1}$ Department of Biochemistry, University of Nebraska-Lincoln, 1901 Vine Street, Lincoln, NE 68588, USA. ²Division of Molecular, Cellular and Developmental Biology, Kansas State University, Manhattan, KS 66506, USA. ${ }^{3}$ Department of Chemical \& Biomolecular Engineering, Johns Hopkins University, 3400 North Charles Street, Baltimore, MD 21218, USA. ${ }^{4}$ Synaptic Research, LLC, 1448 South Rolling Road, Baltimore, MD 21227, USA.

Received: 18 July 2014 Accepted: 9 September 2014

Published online: 25 September 2014

\footnotetext{
References

1. Sørensen I, Domozych D, Willats WG: How have plant cell walls evolved? Plant Physiol 2010, 153(2):366-372.
} 
2. Niklas KJ: The cell walls that bind the tree of life. Biosciences $2004,54: 831-841$.

3. Popper ZA, Michel G, Hervé C, Domozych DS, Willats WG, Tuohy MG, Kloareg B, Stengel DB: Evolution and diversity of plant cell walls: from algae to flowering plants. Annu Rev Plant Biol 2011, 62:567-590.

4. Del Duca S, Verderio E, Serafini-Fracassini D, lorio R, Cai G: The plant extracellular transglutaminase: what mammal analogues tell. Amino Acids 2014, 46:777-792

5. Voigt J, Stolarczyk A, Zych M, Malec P, Burczyk J: The cell-wall glycoproteins of the green alga Scenedesmus obliquus. The predominant cell-wall polypeptide of Scenedesmus obliquus is related to the cell-wall glycoprotein gp3 of Chlamydomonas reinhardtii. Plant Sci 2014, 215-216:39-47.

6. Domozych DS, Sørensen I, Willats WG: The distribution of cell wall polymers during antheridium development and spermatogenesis in the Charophycean green alga, Chara corallina. Ann Bot 2009, 104:1045-1056.

7. Hervé C, Marcus SE, Knox JP: Monoclonal antibodies, carbohydrate-binding modules, and the detection of polysaccharides in plant cell walls. Methods Mol Biol 2011, 715:103-113.

8. Hamers-Casterman C, Atarhouch T, Muyldermans S, Robinson G, Hamers C, Songa EB, Bendahman N, Hamers R: Naturally occurring antibodies devoid of light chains. Nature 1993, 363:446-448.

9. Muyldermans S: Nanobodies: natural single-domain antibodies. Ann Rev of Biochem 2013, 82:775-797.

10. Boder ET, Jiang W: Engineering antibodies for cancer therapy. Ann Rev Chem Biomol Eng 2011, 2:53-75.

11. Corti D, Lanzavecchia A: Broadly neutralizing antiviral antibodies. Ann Rev Immun 2013, 31:705-742

12. Finlay WJ, Almagro JC: Natural and man-made V-gene repertoires for antibody discovery. Fron Immunol 2012, 3:342-355.

13. Maass DR, Harrison GB, Grant WN, Shoemaker CB: Three surface antigens dominate the mucosal antibody response to gastrointestinal L3-stage strongylid nematodes in field immune sheep. Int J Parasitol 2007, 37:953-962.

14. Baral TN, MacKenzie R, Ghahroudi A: Single-domain antibodies and their utility. Curr Protoc Immun 2013, 103:2.17.1-2.17.57. doi:10.1002/ 0471142735.im0217s103.

15. Jiang WZ, Rosenberg JN, Wauchope AD, Tremblay JM, Shoemaker CB, Weeks DP, Oyler GA: Generation of a phage display library of single-domain camelid $\mathrm{V}_{\mathrm{H}} \mathrm{H}$ antibodies directed against Chlamydomonas reinhardtii antigens and characterization of $\mathrm{V}_{\mathrm{H}} \mathrm{Hs}$ binding cell surface antigens. Plant J 2013, 76:709-717.

16. Maggio ET: Enzyme Immunoassay. Boca Raton, FL: CRC Press; 1981.

17. Hornbeck P: Enzyme-linked Immunosorbent Assays (ELISA). In Curr. Protoc. in Mol. Biol. New York: John Wiley \& Sons; 1991:11.2.1-11.2.22.

18. Lequin RM: Enzyme immunoassay (EIA)/Enzyme-linked immunosorbent assay (ELISA). Clin Chem 2005, 51:2415-2418.

19. Posner MR, Antoniou D, Griffin J, Schlossman SF, Lazarus H: An enzyme-linked immunosorbent assay (ELISA) for the detection of monoclonal antibodies to cell surface antigens of live cells. J Immun Methods 1982, 48:23-31.

20. Aida T, Onuma M, Kasai N, Izawa H: Use of live-cell ELISA for detection of monoclonal antibodies recognizing tumor-associated antigens on bovine lymphosarcoma cells. Am J Vet Res 1987, 48:1319-1324

21. Lourenço EV, Roque-Barreira MC: Immunoenzymatic quantitative analysis of antigens expressed on the cell surface (cell-ELISA). Methods Mol Biol 2010, 588:301-309.

22. Blanc G, Agarkova I, Grimwood J, Kuo A, Brueggeman A, Dunigan DD, Gurnon J, Ladung I, Lindquist E, Lucas S, Pangilinan J, Pröschold T, Salamov A, Schmutz J, Weeks D, Yamada T, Lomsadze A, Borodovsky M, Claverie JM, Grigoriev IV, Van Etten JL: The genome of the polar eukaryotic microalga Coccomyxa subellipsoidea reveals traits of cold adaptation. Genome Biol 2012, 13:R39. doi:10.1186/gb-2012-13-5-r39.

23. Coleman AW, Suarez A, Goff L: Molecular delineation of species and syngens In Volvocacean green algae (Chlorophyta). J Phycol 1994, 30:80-90.

24. Hegewald E, Schmidt A, Braband A, Tsarenko P: Revision of the Desmodesmus (Sphaeropleales, Scenedesmaceae) species with lateral spines. 2. The multi-spined to spineless taxa. Apologic Stud 2005, 116:1-38.

25. Nedelcu AM: The complete mitochondrial DNA sequence of Scenedesmus obliquus reflects an intermediate stage in the evolution of the green algal mitochondrial genome. Genome Res 2000, 10:819-831.

26. Hegewald E, Bock C, Krienitz L: A phylogenetic study on scenedesmaceae with the description of a new species of Pectinodesmus and the new genera verrucodesmus and chodatodesmus (Chlorophyta,

Chlorophyceae). FOTTEA 2013, 13:149-164.
27. Hegewald E: Taxonomy and phylogeny of scenedesmus. Korean J Phycol 1997, 12:235-246.

28. Edgar RC: MUSCLE: a multiple sequence alignment method with reduced time and space complexity. BMC Bioinformatics 2004, 5:113-132.

29. Guindon S, Gascuel O, PhyML: A simple, fast and accurate algorithm to estimate large phylogenies by maximum likelihood. Syst Biol 2003, 52:696-704

doi:10.1186/s12870-014-0244-0

Cite this article as: Jiang et al:: A rapid live-cell ELISA for characterizing antibodies against cell surface antigens of Chlamydomonas reinhardtii and its use in isolating algae from natural environments with related cell wall components. BMC Plant Biology 2014 14:244.

\section{Submit your next manuscript to BioMed Central and take full advantage of:}

- Convenient online submission

- Thorough peer review

- No space constraints or color figure charges

- Immediate publication on acceptance

- Inclusion in PubMed, CAS, Scopus and Google Scholar

- Research which is freely available for redistribution
Biomed Central 